\title{
EL GIRO AFECTIVO EN LA HISTORIA DE LA FORMACIÓN HUMANA. MEMORIA DE LA ESCUELA Y EMOCIONES
}

\author{
The affective turn in the history of human formation. A memory \\ of schooling and emotions
}

\section{Agustín Escolano Benito*}

Fecha de recepción: 03/06/2017 • Fecha de aceptación: 06/07/2017

Resumen. Este trabajo analiza algunos aspectos del impacto del affective turn en la historia de la educación, centrándose de modo más específico en la interpretación de los anclajes emocionales que guarda el palimpsesto de la memoria y que se manifiestan en las representaciones textuales, escritas, orales e icónicas, de los sujetos de la formación. Revisa determinados campos que afectan a la reconstrucción de la experiencia vivida en relación con los espacios, los cronos, los dispositivos materiales y otros registros en los que se expresa la cultura empírica de la escuela. Finalmente, plantea la integración de estos elementos de la educación sentimental de los sujetos en los procesos de construcción de la identidad narrativa e incluso en las nuevas perspectivas terapéuticas de la educación patrimonial. Palabras clave: Experiencia, emociones y formación; Giro afectivo e historia de la escuela; Memoria de la educación y representaciones; Memoria e identidad narrativa; Memoria y terapéutica.

Abstract. This paper examines various aspects of the impact that the affective turn had in the history of education. More specifically, it focuses on the interpretation of the emotional underpinnings retained on the canvas of memory that are revealed in textual, written, oral and iconic representations of the subjects. We revise certain fields affecting the reconstruction of experiences relating to spaces, time frames, material devices and other contexts in which the empirical culture of the school is expressed. We then attempt an integration of these elements of the subjects' sentimental education into the processes of the construction of identity narratives and even into the new therapeutical perspectives of patrimonial education.

\footnotetext{
"Centro Internacional de la Cultura Escolar, CEINCE. C/ Real, 35. 42360 Berlanga de Duero, Soria, España.ceince@ceince.eu
}

Cómo citar este artículo: Escolano Benito, Agustín. «El giro afectivo en la historia de la formación humana. Memoria de la escuela y emociones». Historia y Memoria de la Educación 7 (2018): 391-422. 
Keywords: Experience; Emotions and formation; Affective turn in the history of the school; Memory of education and representations; Memory and narrative identity; Memory and therapy.

Solo recuerdo la emoción de las cosas, y se me olvida todo lo demás.

Muchas son las lagunas de mi memoria.

Antonio Machado, Los Complementarios

A este motivo poético invoca el académico Antonio Muñoz Molina cuando presenta la reedición facsímil de la Cartilla Escolar Antifascista, un manual escolar muy singular editado por la Segunda República, en 1937, en plena guerra civil. El texto, como es bien conocido, lo publicó el Ministerio de Instrucción Pública para alfabetizar a los soldados que combatían en los campos de batalla y para suscitar en ellos al tiempo, a través de la lectura, emociones heroicas. ${ }^{1}$

Quienes se iniciaron en la cultura letrada con la anterior cartilla, y sobrevivieron a la guerra, tuvieron en este pequeño libro escolar, en su materialidad textual e iconográfica, un referente simbólico, además de real, con el que recordar emociones que habían sido bien registradas por su memoria. Algo parecido, aunque sin las connotaciones trágicas de la guerra, sucedió a José Jiménez Lozano, Premio Nacional Miguel de Cervantes, cuando encontró en la biblioteca del CEINCE $^{2}$ la cartilla Rayas en la que, por aquellos mismos años, había dado los primeros pasos en la lectura. ${ }^{3}$ Esta reacción emocional es prácticamente universal en los casos de los adultos que visitan las exposiciones de nuestro centro, en las que encuentran a menudo algún texto escolar que ellos mismos utilizaron en su pasado escolar, con el que entablan una relación de empatía emocional que va más allá del mero reconocimiento.

\footnotetext{
${ }^{1}$ Antonio Muñoz Molina, «La emoción de las cosas», presentación inserta en la edición facsímil de la Cartilla Escolar Antifascista (Madrid: Viamonte, 1997, original de 1937).

${ }^{2}$ El Centro Internacional de la Cultura Escolar, dedicado al estudio integral de la cultura de la escuela en perspectiva interdisciplinaria, histórica y comparada, posee en su biblioteca una amplia muestra de este tipo de manuales en diversas lenguas.

${ }^{3}$ Ver: «Nos visitaron: José Jiménez Lozano», Papeles del CEINCE, 13 (2013): 4.
} 


\section{LOS ANCLAJES AFECTIVOS DE LA EXPERIENCIA FORMATIVA}

Todos recordamos la escuela como un espacio real y metafórico del mundo de nuestra vida infantil y adolescente, de cuya memoria emergen anclajes afectivos que transforman la experiencia vivida en fuente esencial de nuestra propia identidad narrativa. El tiempo deviene tiempo humano - escribió el filósofo Paul Ricoeur- en la medida en que se articula y expresa bajo la forma de relato, narratorio sustentado en buena parte en la educación sentimental recibida. ${ }^{4} \mathrm{Y}$ los seres humanos dan sentido al mundo — se reafirmaba el psicólogo Jerome Bruner-contando historias, o sea, usando el modo narrativo de construir la realidad, una práctica discursiva que es en parte una actitud de rebelión frente al racionalismo dominante en los modelos comunitarios al uso, porque en ella afloraban siempre las emociones que se asocian a la experiencia. ${ }^{5}$

La inmersión escolar es un hecho que afecta al mundo emocional. Desde la salida del nicho ecológico de la familia, y a lo largo de todo el proceso de la segunda socialización que ofrece la escuela, el niño —que se metamorfosea en ella convirtiéndose en alumno- se ve sometido al juego que sobre él ejercen los diversos climas y dispositivos de control afectivo que pone en acción el biopoder pedagógico que comportan los mecanismos de la formación: la ergonomía de los nuevos espacios y enseres muebles; los biorritmos de los cronos institucionales que se superponen a los domésticos; los códigos de la urbanidad, la disciplina y el ritualismo que rigen la gobernanza en la educación; las sutilezas del pudor, de la seducción y del humor que acompañan a los lenguajes educativos; las estructuras textuales de los manuales y las reglas de la escritura; los mensajes de la iconografía con que se inundan los ámbitos de la institución... Todos los elementos que definen el régimen escolar comportan, cada uno por separado y como conjunto, una semántica que ejerce sobre toda la infancia una educación sentimental bien definida y de influencia duradera, que con el pasar del tiempo reaparece en los recuerdos de los adultos.

Este trasfondo cargado de afectividad no solo acompaña a los elementos cognitivos de la formación; potencia o neutraliza asimismo otros mecanismos complejos. Con ello, las vivencias emocionales contribuyen

\footnotetext{
${ }^{4}$ Paul Ricoeur, Tiempo y narración III. El tiempo narrado (México: Siglo XXI, 1996).

${ }^{5}$ Jerome Bruner, La educación, puerta de la cultura (Madrid: Visor, 2000), 149-150.
} 
a conformar la subjetividad humana, lo que se manifiesta cuando aflora en el narratorio de las biografías cualquier estímulo que activa la memoria. Ello es así porque la cultura de la escuela es un conjunto holístico de cogniciones y emociones en interacción. Al sonar una canción aprendida en la infancia se activa una emoción antigua que está integrada en el palimpsesto de los recuerdos, nuestro sustrato antropológico. Lo mismo sucede al encontrarnos con la cartilla en la que comenzamos a leer o el cuaderno en el que dejamos registro gráfico de nuestras primeras huellas escribanas. Y por supuesto, algo dejaron en nuestra sociabilidad afectiva los pares de edad con los que cohabitamos durante años en las aulas y en los patios de recreo, o los enseñantes que nos educaron, apercibieron, premiaron o castigaron. Nadie olvida desde luego un buen maestro, ni tampoco a un dómine disciplinante.

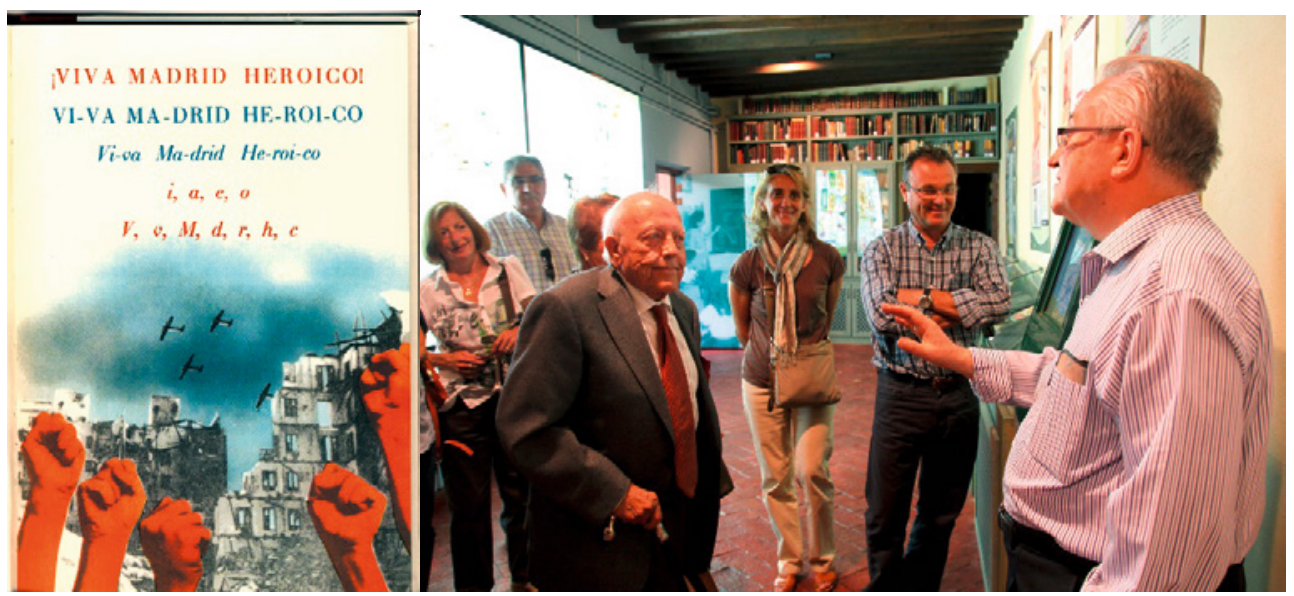

\section{EMOCIÓN Y LETRAS. APRENDER A LEER EL MUNDO}

Lo dijo Paulo Freire: aprender a leer es aprender a leer el mundo. Las imágenes que se ofrecen aquí corresponden a las experiencias aludidas en la introducción a este trabajo. En la Cartilla Militar Antifascista empezaron a poner nombres a las cosas los jóvenes soldados iletrados que descubrían el mundo en el frente de batalla. El intelectual Jiménez Lozano se emociona al encontrarse con el libro en el que empezó a dar los primeros pasos en una actividad que ha dado sentido a toda su vida. 

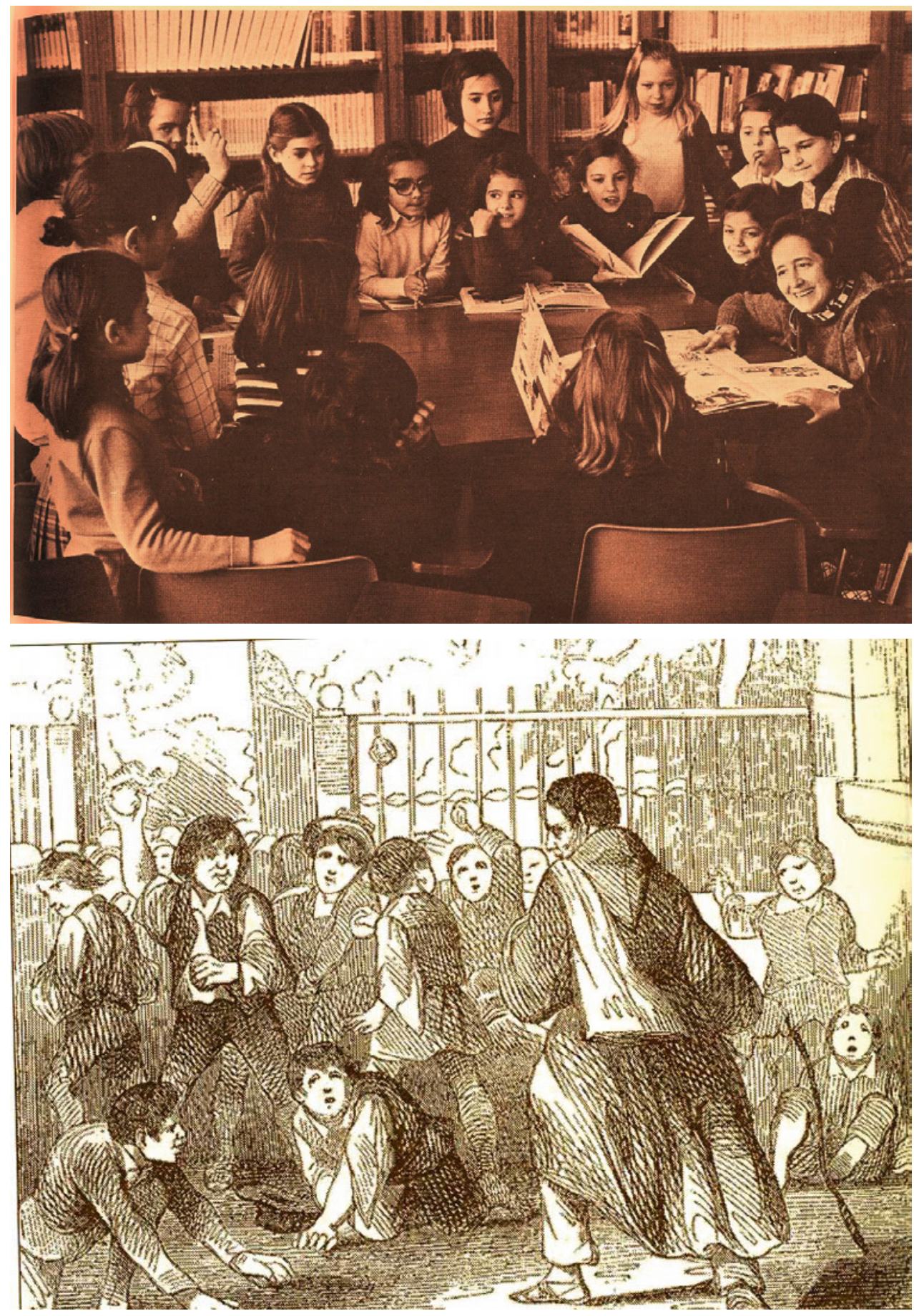


\section{ENTRE EL PLACER Y EL DOLOR}

Nadie olvida a un buen maestro ni a un dómine disciplinante. Las imágenes ofrecen una sesión de lectura en la biblioteca de una escuela barcelonesa, en 1934 (La Vanguardia) y la reproducción en forma de grabado de una escena en la que un dómine fustiga con sadismo a un grupo de niños y adolescentes (Elche, siglo XIX).

La escuela ha sido siempre un lugar de paso en el que se han practicado el amor y la disciplina, el placer y el dolor.

La historia de la escuela no puede ignorar la dimensión emocional de la formación humana. El pasado formativo no es desde luego el resultado de ningún logos discursivo, riguroso tal vez en sus supuestos y métodos, pero siempre externo al mundo vivido. Tampoco es el efecto inducido por un proyecto presuntamente emancipatorio, en parte programático y en parte mitologizado. La cultura escolar que interesa al historiador es la que se gesta en las prácticas empíricas que acontecen en contextos reales y que son puestas en acción por sujetos que operan, a menudo de modo sinérgico, con cogniciones y emociones. De ello habla en nuestro tiempo la nueva neurociencia unitarista, de orientación neospinoziana, superadora de la episteme dual que el mundo moderno heredó de Descartes. ${ }^{6}$ Las prácticas educativas, que se han generalizado en todas las poblaciones al hacerse universal la escuela, han construido una nueva subjetividad y una nueva cultura, dando origen además a una renovada antropología y a innovadoras formas de sociabilidad, que incluyen también el mundo de las emociones.

Antonio Valleriani, fundador del Círculo Hermenéutico de Teramo, en Italia, al hablar de la "hermenéutica de la infancia», recurre al ludus y al teatro para indagar en las simbolizaciones que se expresan en estas prácticas escénicas las claves explicativas del juego interactivo entre lo cognitivo y lo emocional. ${ }^{7}$ En efecto, son los gestos, las máscaras y los ritos los sintetizadores del habitus que combina el conocimiento y la afectividad en los procesos de formación. El gesto es expresión del rostro, un rictus

\footnotetext{
${ }^{6}$ Antonio Damasio, Y el cerebro creó al hombre (Barcelona: Destino, 2010), 176 ss.

${ }^{7}$ Antonio Valleriani (ed.), Il gioco, el volto e la maschera. Per un'ermeneutica dell'infanzia (Teramo: Andromeda, 2001).
} 
emotivo que ya observó Darwin, incluso en los animales. La máscara es la cara visible de la personalidad, un interfaz que muestra y oculta signos emocionales al tiempo. El rito es la ceremonia que pauta las reglas sociales que rigen en la convivencia escolar, controlando los sacrificios que ha de asumir la espontaneidad infantil para acomodarse a las exigencias de la vida en comunidad. Todas estas conductas tiñen la emotividad de los sujetos, tanto en su ejecución como en el relato de su recuerdo.

Este breve trabajo se sitúa en la genealogía y construcción sociohistórica de esta cultura de las emociones y los sentimientos, ignorada hasta ahora por los analistas del pasado de la formación, más proclives al idealismo y al historicismo. Desde la nueva episteme que emerge con el impacto de llamado affective turn en la historiografía, y en las ciencias humanas y sociales en general, nuestro ensayo analiza algunas prácticas en las que se materializa la puesta en acción de los dispositivos del biopoder educativo. También examina ciertas representaciones de las emociones en la historia registrada y en la memoria de los sujetos. Espacios, tiempos y escrituras son, además de estructuras materiales de la educación, registros visuales y etnográficos con fuerte carga semántica y referentes de la memoria de lo vivido. En lo que afecta a la oralidad, la memoria relatada es una fuente esencial que complementa la arqueología de lo material, tejiendo con viveza la construcción de las imbricaciones que operan entre lo cognitivo y lo emocional.

\section{LAS NUEVAS DIMENSIONES DE LO EMOCIONAL}

En la actualidad, no solo es la psicología la que ha postulado la existencia de una inteligencia emocional. ${ }^{8}$ La politología ha introducido recientemente el concepto de psicodemocracia para tratar de explicar los nuevos comportamientos ciudadanos en cuyas decisiones intervienen no solo las razones de la lógica y el interés sino también los móviles del prejuicio y de las emociones. El ensayo de Gabriele Giacomini, intitulado Psicodemocrazia, alude a las evidencias históricas del peso de la irracionalidad en el ascenso social de los fascismos y populismos, algo que los historiadores de la educación hemos documentado suficientemente, para luego adentrarse en la interpretación de muchos comportamientos

\footnotetext{
${ }^{8}$ Daniel Goleman, Inteligencia emocional (Barcelona: Kairós, 1996).
} 
sociopolíticos de nuestro tiempo, en los que la fascinación de lo irracional, el narcisismo de los liderazgos y las retóricas de la seducción condicionan la praxis y el discurso de lo público. Ello explica en parte que el Oxford Dictionary haya incluido en sus dos últimas ediciones los términos emoji y post-truth. El primero alude al pictograma que expresa al tiempo emociones conforme a criterios que pueden variar culturalmente, incluidas las bipolares como la tristeza y la alegría, un hecho de fusión que se muestra hoy, como se manifestaba en otras épocas en culturas arcaicas. La posverdad se refiere al peso que lo emocional ha adquirido actualmente en la conceptualización de la realidad y a los condicionamientos de la irracionalidad sobre los presupuestos objetivos en cuestiones relevantes que afectan a la sociedad posmoderna y a la convivencia en democracia. ${ }^{9}$

En un plano más pragmático, la moderna economía viene subrayando el interés de la neurociencia por conocer el impacto de las emociones, así como de los sentimientos de identificación y empatía, en determinadas decisiones relativas al consumo de bienes y hasta en los resultados finales de las empresas. ${ }^{10}$ En la filosofía de la cultura, George Steiner ha llamado la atención acerca del peligro que la educación mate los sueños de la infancia - primero mitos, después hechos, proclamó hace un siglo José Ortega y Gasset-y aboque a la reaparición del idiotes aristotélico, el sujeto no-ciudadano, un individuo sin rumbo y sin sentido en la vida de la polis, entregado a las derivas posmodernas, cargadas todas ellas de notorios componentes de irracionalidad. ${ }^{11}$

Todas las disciplinas humanas, pues, acusan hoy el influjo del affective turn y revisan sus respectivas epistemes y sus programas de investigación. Esta contribución nuestra sugiere modos de revisión de la historiografía educativa, un campo académico hasta ahora demasiado teñido de idealismo y de ilusiones pseudoliberadoras, y poco atento a las saludables razones de la práctica a las que invitaba el sociólogo Pierre Bourdieu, móviles que no excluyen los componentes simbólicos de las

\footnotetext{
${ }^{9}$ Gabriele Giacomini, Psicodemocrazia. Quanto l'irracionalità condiziona el discurso público (Milano: Mimesis, 2016).

${ }^{10}$ Richard Barrett, A new psychology of human well-being (London: Barrett Values Centre, 2015).

${ }^{11}$ George Steiner, Lecciones de los maestros (Madrid: Siruela, 2005).
} 
emociones y las pasiones que han operado siempre en el mundo de lo factual. ${ }^{12}$

En estas perspectivas que introduce la historia de las emociones residen justamente ciertas claves que ayudarán a entender algunas de las distorsiones que han deformado, eludido o silenciado los analistas del pasado de la formación. Acercar la historia educativa a estos abordajes es también una operación intelectual que introducirá un humanismo más culto y profundo en la comprensión del pasado y del presente de nuestra educación, y que acercará además nuestra disciplina al diálogo con otros saberes, no solo humanísticos sino incluso del ámbito de las ciencias biológicas, una perspectiva que en otro tiempo pudo parecer una deriva extraña e inoportuna, pero que hoy se percibe como un horizonte fecundo en la empresa de conocer más globalmente la condición humana y el hecho de la formación de los individuos.

\section{MEMORIA DE LAS EMOCIONES}

Uno de los últimos trabajos del historiador inglés Richard Aldrich se sitúa precisamente en la encrucijada que intenta fusionar las humanidades con la ciencia. En él se propone la concepción del cerebro humano como una estructura compleja en la que se pueden explorar diferentes capas arqueológicas, impresas en ella a modo de un palimpsesto, enfoque al que ya aludimos en el epígrafe introductorio. La memoria también habría quedado depositada en diversos niveles o registros que el recuerdo y la investigación exhuman y ofrecen al análisis y a la interpretación. Según este modelo de estudio, nuestras experiencias vividas - tanto las asociadas a las cogniciones como las que afectan al mundo de las emociones- habrían sido acumuladas en diferentes estratos de nuestra memoria personal, y por extensión y generalización, en las tramas de la memoria colectiva.

Una de las vías de acercamiento al estudio de las relaciones del mundo emocional con la historia de la formación humana es el relativo al estudio de las representaciones que han permanecido fijadas en la memoria de los sujetos y en las culturas. Tales imágenes afloran y se expresan

\footnotetext{
12 Pierre Bourdieu, El sentido práctico (Buenos Aires: Siglo XXI, 2007), 148-149.
} 
mediante narratorios, orales o escritos, o en otras conductas relativas a la recuperación de los recuerdos. A menudo estas representaciones no son tan fiables como las visuales, toda vez que la memoria, según nos advirtió Jorge Luis Borges, es una de las monedas más falsas puestas en circulación en los diálogos intersubjetivos. La memoria sufre deformaciones, metamorfosis, idealizaciones, olvidos y otros trastornos y desvíos, muchos de ellos condicionados también por las intenciones y los sentimientos de los sujetos y de los investigadores. Es, en palabras del mismo Borges, como un museo de formas inconstantes y volubles, que aparecen en un caleidoscopio de espejos deformantes. ${ }^{13}$ Incluso en ocasiones, como advierte el novelista portugués José Eduardo Agualusa, la memoria personal se nutre en buena medida de aquello que los otros recuerdan de nosotros, pudiendo en este caso recordar como nuestros los recuerdos ajenos, que pueden hasta ser ficticios. ${ }^{14}$ Pero puestas las memorias reconstruidas en interacción, la química que se opera entre ellas produce construcciones culturales que trascienden el plano de lo biográfico y conducen a planteamientos culturales de gran interés, no solo histórico sino también antropológico. Así sucede con el uso que se viene haciendo de la oralidad en diversos trabajos de ciencias humanas y sociales.

Los recuerdos nos asaltan a veces ante determinados estímulos emocionales competentes - para decirlo en la conocida terminología de Antonio Damasio- que aparecen en nuestro horizonte. Una nueva experiencia perceptiva o afectiva desencadena un proceso cognitivo-emocional en el que lo nuevo se pone en conexión con el pasado, con la memoria. En otras ocasiones, el reencuentro con las materialidades, las situaciones o los actores que han formado parte de nuestro pasado formativo promueve relatos, sentimientos de nostalgia y otros ejercicios anamnéticos que ponen en valor a la memoria, tanto en el plano psicosocial como en el histórico-cultural. En los puntos que siguen trataremos de aproximarnos al conocimiento del mundo emocional vinculado a ciertos aspectos significativos de la vida en la escuela, analizando las representaciones expresas o implícitas que se nos presentan en los actos de memoria.

\footnotetext{
${ }^{13}$ Jorge Luis Borges, Poesías (Barcelona: RBA-Instituto Cervantes, 2005), 997.

${ }^{14}$ José Eduardo Agualusa, $O$ vendedor de pasados (Lisboa: Publicaçôes Dom Quixote, 2004), 163.
} 


\section{LOS ESPACIOS VIVIDOS}

Los lugares y espacios en los que estuvo instalada la escuela han sido probablemente los marcos de referencia que mejor ha guardado la memoria. Antes que los contenidos, los actores, los métodos y otros elementos de la cultura escolar, los sujetos educados recuerdan los escenarios en que transcurrió su formación. Lo mismo sucede con las representaciones iconográficas en que quedó acreditada la escuela como prueba visual de su existencia y de sus características, así como de su sentido de espacio simbólico de aprendizaje y de sociabilidad. Aludiremos a él tomando como referencia la memoria que los sujetos han conservado de estos ámbitos en los que se llevó a cabo su primera escolarización, lugares que han quedado emocionalmente vinculados a la memoria biográfica de las personas.

Para ilustrar lo anterior, vamos a relatar dos experiencias estrechamente ligadas a los entornos en que ha transcurrido la vida del autor de este texto. Una es estrictamente personal y alude a las emociones que experimentó el narrador al encontrase, ya en edad madura, con los espacios de la escuela a la que asistió en la infancia. La otra procede de una experiencia colectiva suscitada con ocasión del encuentro de un grupo de investigadores del Centro Internacional de la Cultura Escolar (CEINCE) en un pequeño museo-escuela existente en la zona, hecho que propició reacciones emotivas al actuar este escenario como situación desencadenante de estímulos que hacían aflorar memorias emocionales archivadas en el palimpsesto de las mentes de los participantes en el experimento. La una es de carácter más biográfico; la segunda, al ser colectiva, revela emociones y sentimientos más estructurados que acreditan las interrelaciones existentes entre las culturas escolares de medios diversos y la construcción de la subjetividad y la memoria social. A ambas nos hemos referido en otros trabajos, aunque se retoman aquí en el contexto de este trabajo que analiza el binomio educación-memoria.

El protagonista del primer relato visitó la escuela a la que asistió en su infancia, entre los seis y los diez años de edad. En el paseo por el edificio y sus patios pudo observar que aquel contenedor arquitectónico había sufrido varias reformas a lo largo del último medio siglo para ser adaptado a las exigencias de modernización material y pedagógica de cada época. A modo de capas arqueológicas superpuestas, podían observarse en él dos adaptaciones, las derivadas de las reformas de 1970 y de otra posterior. 
No obstante, la fábrica arquitectónica aún conservaba la vetusta estructura y traza de cuando se construyó, en los últimos años de la Dictadura de Primo de Rivera (su apertura se llevó a cabo a comienzos de la Segunda República). Planos y alzados se identificaban bien con los patrones que diseñó la Oficina Técnica de Construcciones Escolares, dirigida por el conocido arquitecto krausoinstitucionista Antonio Flórez. Este fue un modelo de escuela graduada que se implantó en numerosos lugares del país, al que tanto sus usuarios como los historiadores interesados en el patrimonio guardan una alta estima. El patrón había acertado en dotar a la escuela primaria española de una imagen institucional digna, próxima a la estimativa que concebía los nuevos centros como «templos de saber».

El narrador introdujo los anteriores comentarios en la conversación con los acompañantes, maestros de la escuela y amigos del lugar, algunos de ellos. El visitante notó asimismo que aquel contenedor material renovado aún seguía sirviendo de soporte físico para la colocación de ciertos símbolos como las banderas y los retratos de autoridad, compatibles con los cambios políticos asociados a los nuevos tiempos. Era pues aquella fábrica arquitectónica un sintetizador de reformas pedagógicas, en el que también se insertaban ciertos elementos estructurales y simbólicos estables. ${ }^{15}$

En lo que afecta a la historia de las emociones, el observador pudo identificar los ámbitos de sus primeras experiencias escolares, los espacios vividos en la infancia, que no había desalojado aún de su memoria, a los que se sentía unido por sentimientos de identidad, y ahora de nostalgia. Las aulas le parecían más reducidas y los pasillos más estrechos, aunque en realidad no eran muy diferentes a los espacios que él conoció. La escalera por la que se accedía a la planta superior, donde se ubicaban las clases de las niñas, le resultaban más accesibles y hasta con menos peldaños. Pero la memoria no le era infiel: el espacio que contemplaba sí era el mismo escenario de su infancia y se correspondía con sus primeros esquemas perceptivos. La escuela había sido para el relator, después de su casa familiar y de algunos aledaños próximos a ella, un lugar de experiencias decisivas en el aprendizaje de las primeras estructuras topológicas y en la formación de su esquema corporal. Estas experiencias incluían percepciones y emociones, ahora revividas al recuperar los

\footnotetext{
${ }^{15}$ Agustín Escolano Benito, «La arquitectura como programa. Espacio-escuela y currículum», Historia de la Educación, 12-13 (1993-94): 97-99.
} 
recuerdos entrando en contacto con estímulos competentes capaces de reactivar los afectos asociados a la memoria personal.

La narración nos muestra la arraigada impronta que las primeras experiencias físicas, cognitivas y emocionales del espacio escolar dejaron en el observador, aunque los recuerdos se pudieran revivir bajo esquemas en parte reductivos y algo transformados en el diseño y en su estética. El relato daba igualmente testimonio de los procesos primarios de acomodación psicofísica que vivió el sujeto en la infancia y de la construcción de las pautas y los gestos corporales, que en parte aún se podían comprobar en los hábitos de comportamiento que él mismo reconocía en sus modos de relación con las gentes y con el mundo de la vida.

Envuelto en esta atmósfera emocional revivida, el autor del relato volvió a su antigua casa, en la que, junto a sus abuelos, padres y hermanos, habían transcurrido varios años de la niñez. Al igual que Yambo, el personaje del conocido relato de Umberto Eco que había sufrido un ictus, ${ }^{16}$ el visitante subió al desván, espacio donde encontró varios testimonios de su escolaridad: la cartilla Rayas donde dio los segundos pasos en el aprendizaje de la lectura (los primeros los había dado con su padre en casa); la enciclopedia Dalmáu Carles, fuente de un repertorio completo de sucintos y esquemáticos conocimientos acerca de todas las materias del programa; un viejo cuaderno de caligrafía, dibujo y problemas aritméticos; otros objetos escolares como el cabás, la regla de medir y trazar rectas y una pequeña esfera anterior a la guerra mundial. Todo un utillaje - pensó- que no era un montón de basuras de una escuela arcaica y periclitada sino toda una serie de materialidades que ofrecía signos de una cultura con huellas que revelaban muchas claves afectivas de su vida infantil. Un conjunto de cosas que junto a otras deberían pasar a formar parte de un museo etnohistórico de la escuela que algún día habría que promover como registro de una cultura y de un tiempo, y en orden a la educación patrimonial de los ciudadanos. El primer orden del mundo que se recuerda —escribe Javier Pérez Andújar- es el que se aprendió en la cartilla con las primeras letras y con la enciclopedia de la vieja escuela. ${ }^{17}$ Con los signos letrados, al aprender a leer, pusimos nombre a las cosas y al mundo. Como añadidura, la enciclopedia nos proporcionó

${ }^{16}$ Umberto Eco, La misteriosa llama de la reina Loana (Barcelona: Lumen, 2005).

${ }^{17}$ Javier Pérez Andújar, Diccionario enciclopédico de la vieja escuela (Barcelona: Tusquets, 2016), 14. 
la vulgata epitomizada de las disciplinas con las que pertrechar nuestra mente para iniciar el viaje de nuestra vida por el mundo.

La segunda experiencia se describe glosando la imagen que se muestra más abajo. El espacio corresponde a una escuela rural de la pequeña aldea de Bordecorex, próxima a Berlanga de Duero, localidad donde tiene su sede el CEINCE. Clausurada en 1966, tras el éxodo de la población, hace pues medio siglo, los habitantes que emigraron y los que quedaron en el lugar decidieron dejarla tal como estaba, como museo. Era una decisión de igual significado que la del museo de Otones de Benjumea, en la vecina provincia de Segovia, que sus propios creadores han denominado «La última escuela». Ambas creaciones son, a nuestro entender, formas simbólicas de resistencia de la memoria biográfica y de la colectiva a la extinción, una prueba de la tendencia a conservar la tradición del lugar, así como un gesto de afirmación emocional y social de la identidad de una comunidad ante los procesos de cambio que amenazan la disolución de los lazos sociales tradicionales entre los miembros pertenecientes a estas microsociedades rurales. ${ }^{18}$

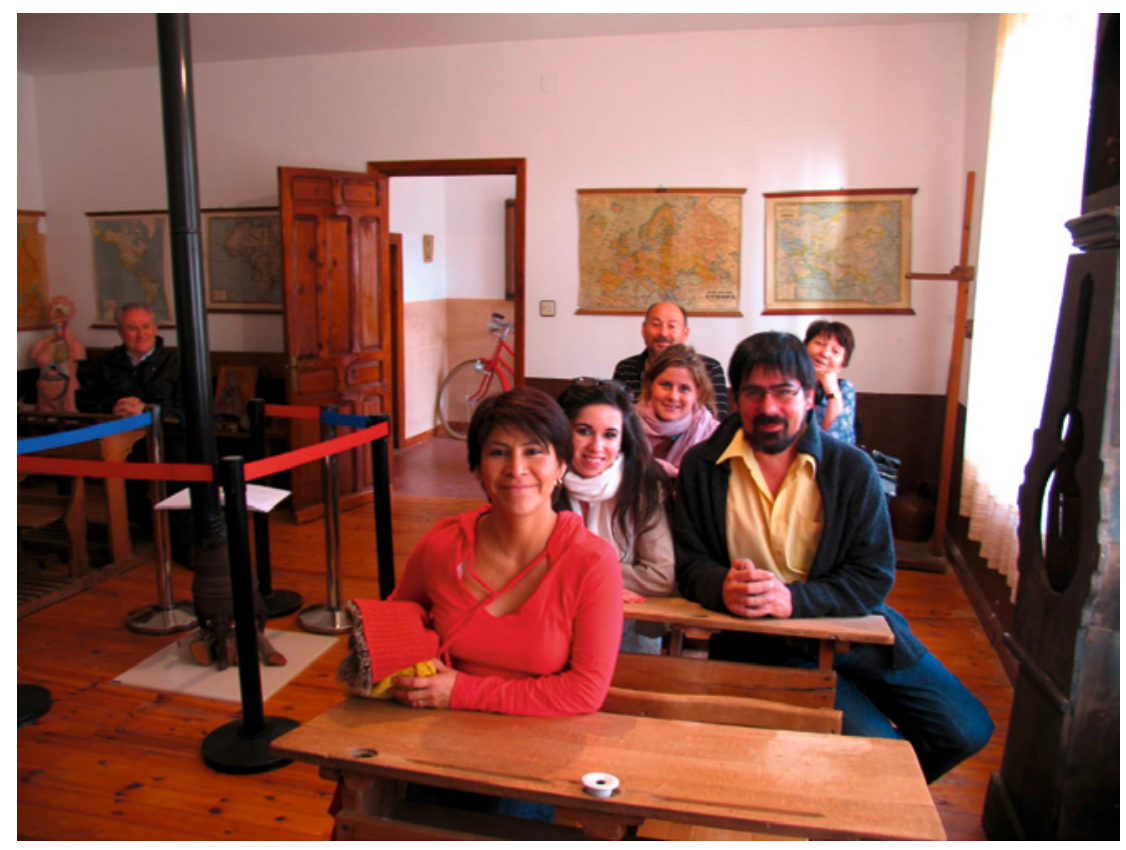

${ }_{18}$ Agustín Escolano, La cultura empirica della scuola. Esperienza, memoria, archeologia (Ferrara: Volta la Carta, 2016), 191 ss. 


\section{MEMORIA EMOCIONAL DE LA ESCUELA}

Escenografía tomada con ocasión de la estancia de un grupo de jóvenes investigadores en historia de la educación, de diversos países y edades, en el CEINCE. Corresponde a la escuela-museo de Bordecorex, Soria (mayo, 2012).

Esta imagen ha sido ya utilizada en otras publicaciones nuestras, aunque en cada caso con comentarios adecuados al tema que se ilustraba. Es sin duda una escenografía polivalente que admite varias lecturas. Aquí se ofrece como representación de la historia de las emociones.

El escenario aparece ocupado por varios actores, cada uno de diferente procedencia: México, Granada (España), Montevideo (Uruguay), Göttingen (Alemania), Mar del Plata (Argentina), Berlanga (España). Fuera de escena dos actores más: uno de Ferrara (Italia) y el autor de la fotografía, de Sevilla. Los sujetos de la escena esbozan, como puede observarse, una misma sonrisa, expresión de una respuesta emocional semejante, o de parecida intención. No importa que la infancia escolar de cada actor hubiera transcurrido en latitud diferente, distantes entre sí todas ellas. La sincronicidad y similitud de todas las miradas, aun sin interaccionar unas con otras, revela la existencia en todas y cada una de ellas de memorias emocionales asociadas a experiencias comunes vividas en diferentes lugares y en distintas épocas históricas. Ello manifiesta al menos dos cosas: a) que los espacios-escuela vividos, cada uno en su respectivo país y tiempo, tenían algo en común; b) que la estructura material de esos espacios se había mantenido relativamente estable a lo largo de varias generaciones, hasta el punto de poseer una cierta identidad común en los elementos básicos.

Las memorias compartidas podrían extenderse también al recuerdo que los cuerpos guardan de las reglas de la ergonomía escolar. La estructura antropométrica que hoy exhiben estos sujetos se ajusta mal a las medidas de los viejos pupitres, en los que logran insertarse con suma dificultad. No obstante, la corporalidad, que es además de una composición física una construcción cultural y un acumulador de aprendizajes, recuerda bien la cinética, las actitudes y los modos de ajuste a los muebles que sometieron a la infancia a determinadas ortopedias del biopoder pedagógico. Nótese también que, una vez logrado el acoplamiento sujeto-pupitre, los cuerpos mues- 
tran un cierto confort emocional, así como la satisfacción del reencuentro con sentimientos arraigados en los sujetos desde la ya lejana infancia.

Más allá de las acomodaciones físicas a los condicionamientos materiales de la escuela antigua, los sujetos de la experiencia de Bordecorex han percibido y vivido el museo como un escenario estimulante de emociones y sentimientos positivos bien archivados por las memorias, los que se reflejan en las sonrisas. La escuela-museo, una realidad ya histórica, se habría constituido en esta circunstancia en un estímulo emocional adecuado para poder desencadenar respuestas teñidas de afectividad.

Por otro lado, debe considerarse que todas las personas que intervienen en esta experiencia son historiadores de la educación que en ese momento se encontraban llevando a cabo estancias de investigación en el Centro Internacional de la Cultura Escolar. Esta salida de campo, en busca del encuentro real con yacimientos arqueológicos, sacó a los investigadores del archivo y la biblioteca y les introdujo en una situación real que les invitaba a transformarse en arqueólogos y a adoptar una mirada etnográfica sobre los restos materiales de una escuela del pasado, así como a dialogar desde sus respectivos recuerdos con la memoria subyacente en aquellas ingenuas materialidades y con sus propios esquemas intelectuales como historiadores del campo.

Esta actividad generó al mismo tiempo en los observadores emociones y reflexividad, dos conductas que influyeron en la comprensión e interpretación de los significados adheridos a las materialidades que percibían. El encuentro con el museo dio origen después a diversos narratorios e explicaciones cargados de subjetividad emocional, lo que abocó a la constitución sobre el terreno de una comunidad hermenéutica rica en lecturas y modos de expresión, decidida a desvelar e interpretar la memoria de aquellas materialidades observadas, así como de aquellas otras que ellos mismos recordaban de su propia experiencia biográfica.

Pues bien, en estas dos narrativas que afectan a los espacios escolares vividos están presentes las emociones y los sentimientos de los autores de los relatos, junto a las percepciones, los procesos cognitivos e incluso los comportamientos psicomotores de los sujetos participantes. La memoria, además de un palimpsesto, es un registro holístico de las experien- 
cias y de las representaciones que se han creado a partir de la interacción con el mundo de la vida, y en nuestro caso, con el de la educación.

\section{ORALIDAD Y MEMORIA EMOCIONAL}

Continuando con el análisis de la presencia de las emociones en los relatos que recogen las memorias de la experiencia escolar de los sujetos, ofrecemos en este epígrafe algunos testimonios procedentes de una interesante investigación doctoral llevada a cabo recientemente por Marilia J. Rodrigues, bajo la dirección del profesor Xosé Manuel Cid, en el territorio transfronterizo de las comarcas limítrofes entre el norte de Portugal (Tras-os-Montes) y el noroeste de España (Galicia y Castilla y León). El trabajo afecta a la memoria escolar de los sujetos - hoy ya adultos-que asistieron a la escuela durante los dos largos períodos históricos de las dictaduras que afectaron a ambos países, el Estado Novo y el franquismo, y se fundamenta en los datos recogidos directamente mediante entrevistas personales aplicadas ad hoc. El guion de las entrevistas es una adaptación de uno que nosotros mismos propusimos hace algún tiempo como instrumento de trabajo de informantes que recogían memorias de escuela en un trabajo de carácter etnohistórico. ${ }^{19}$

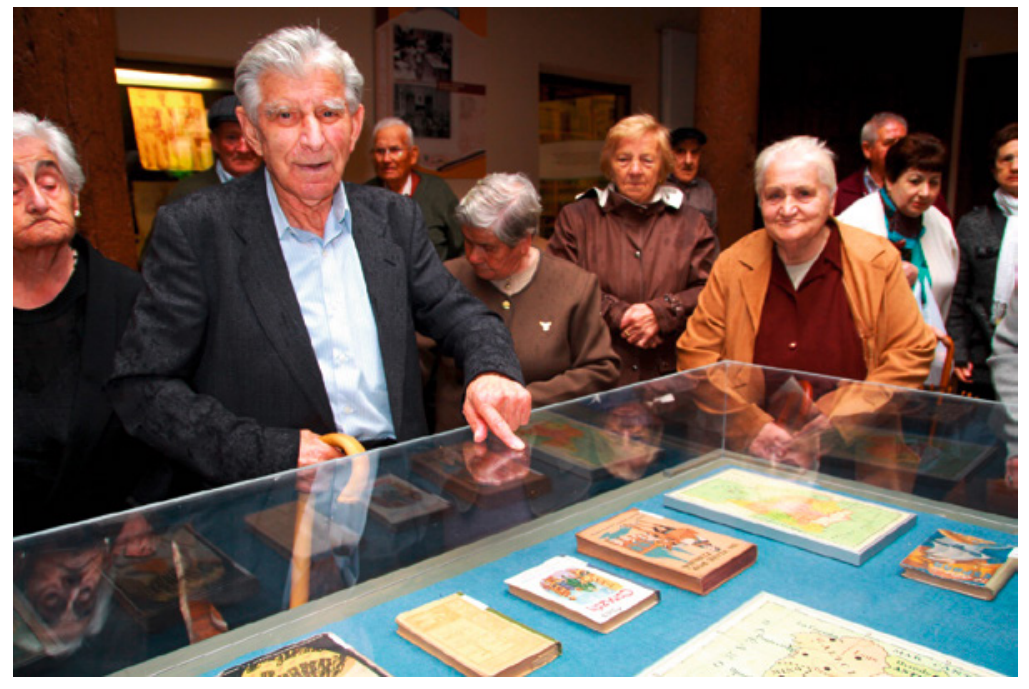

${ }^{19}$ Marilia J. Rodrigues Gomes, A realidade educativa no nordeste portugués e nas escolas castelhano-leonesas e galegas fronteiriças, através da memoria oral, na época das ditaduras (Tesis Doctoral, Campus Ourense-Universidad de Vigo, 2015), 377 ss. 


\section{MEMORIA TEXTUAL}

Escena de la visita de un grupo de mayores a la exposición «Mi Querida Escuela» del CEINCE. Cecilio, uno de los miembros del grupo, sonríe al encontrarse con uno de sus libros de lectura infantiles preferidos, el Corazón, de Edmundo de Amicis, del que recitó de memoria algunos pasajes.

De profesión pastor, en toda la trayectoria de su vida activa, Cecilio nos recordó en su visita, con emoción contenida, las muchas horas que dedicó a la lectura cuando sus padres le destinaron al cuidado de los ganados familiares. Los acompañantes del grupo asentían con gestos afectivos al reconocer los contenidos de la recitación, lo que era otro ejercicio de memoria.

Este tipo de estudios, más allá de sus encuadres sociopolíticos, tiene un fuerte calado antropológico, toda vez que los análisis afectan al conocimiento de las mentalidades colectivas lentamente formadas en el tiempo y que sólo se transforman en ciclos de larga duración. Por eso, muchos de los contenidos que conserva la memoria emocional de los sujetos entrevistados son expresión de patrones muy estructurados y consolidados en forma de habitus. Se adscriben en realidad al ethos y al imaginario de las sociedades agrarias tradicionales que se sitúan en estadios histórico-evolutivos muy anteriores a los cambios promovidos por la industrialización y la modernización. Los territorios trasmontanos, gallego y castellano-leonés, de la llamada raia entre fronteras, aun marcados por ciertas diferencias de lengua, cultura y tradiciones, se sitúan en los niveles de desarrollo socioeconómico anteriormente comentados, en alguna medida comparables.

Para ejemplificar la aportación de este trabajo transcribimos algunos testimonios que afectan a la memoria emocional de los sujetos participantes en la experiencia, comenzando por contenidos que definen la misma imagen de la infancia y la vida cotidiana de las escuelas que recuerdan los entrevistados portugueses.

Tenía que ir a pie a la escuela, pero antes había de tener hechos muchos trabajos a mi madre, por lo que llegaba con retraso. La profesora no me dejaba entrar por llegar tarde. Mientras tanto, yo 
andaba por los campos, escondida. Me comía la merienda. Permanecía así hasta que los demás salieran de la escuela. Después me juntaba con ellos e íbamos a casa. Faltaba muchas veces por ayudar a mi madre. Solo aprendí a escribir mi nombre. Me hubiera gustado haber aprendido más cosas (Chaves, nacida en 1922).

Las vivencias de la escuela me marcaron para toda la vida y moldearon mi personalidad (Chaves, nacido en 1944).

Mis recuerdos de infancia no son destacables, aunque son mucho más. Mi padre me pegaba por no ser capaz de aprender y en la escuela el maestro me dejaba encerrado (Vimioso, nacido en 1936).

Me gustaba mucho ir a la escuela; también me gustaba mi profesora. Nunca me castigó, aunque yo nunca lo precisaba. Estudiaba y hacía los deberes. Tenía allí buenos amigos (Vinhais, nacida en 1924).

La alegría inicial quedaba mitigada por la obligación de levantarnos temprano y de hacer los deberes en casa a la luz de una vela. Si no se hacían por convicción, era por miedo. La señora profesora tenía una palmatoria como una de las técnicas más eficaces de aprendizaje (Chaves, nacida en 1945).

Mi escuela era linda y acogedora. No era grande, pero conseguía acoger a unos 60 alumnos, de todas las clases. Tenía las paredes pintadas de blanco. Tras la mesa de la maestra había un crucifijo colgado en la pared (Miranda do Douro, nacida en 1924).

Un día la maestra puso a Antonio y a Guida las orejas de burro y colocó a los dos a uno y otro lado de la pizarra. Mandó callar, pero yo me reí. Ella se vino hacia mí con las orejas. Mis compañeros se echaron a reír (Miranda do Douro, nacido en 1933).

Si nos internamos en las escuelas de las regiones relativas a España, el tenor de los recuerdos no era en realidad muy diferente a los anteriores, aunque las referencias locales y las circunstancias de cada entorno local puedan hacerlos variar en algunos contenidos, no tanto en las actitudes afectivas o en el contexto emocional en que vivían los sujetos. 
En mi casa hacíamos veladas nocturnas y se contaban historias. No se leía. Mi padre y mi madre sabían leer, pero muy poco. Tenían muchos hijos y había que trabajar (Mezquita, nacido en 1957).

A comienzos de los años sesenta empezó la emigración a los países de Europa. Los padres dejaban a sus hijos con los abuelos, tíos o vecinos, y con gran tristeza se iban a trabajar. Luego, con sus ahorros ponían a los hijos a estudiar. Aquello fue un cambio total [...] Las familias feudales que tenían las propiedades no aceptaban que los hijos de los más pobres pudiesen ponerse a la altura de los más ricos [...] Los padres nos decían que la escuela era necesaria para mejorar la vida (Verín, varios nacidos entre 1937 y 1951).

La escuela era vieja y tenía dos ventanas grandes, pero no luz eléctrica. Los pupitres eran de madera para dos alumnos. No había patio de recreo. Era una escuela mixta para 40 alumnos de todos los cursos (Alcorcillo, nacido en 1946).

Daba clases con el método expositivo. Motivaba a los alumnos con juegos y jugaba con ellos. Oí hablar de Freinet, Decroly y otros, pero cuando estudié Magisterio no me hablaron de ellos (Fermoselle, nacido en 1949).

El maestro castigaba con los brazos en cruz, con un libro en cada mano y sin recreo. Yo solo me quedé una vez sin recreo; nunca más fui castigada (Mezquita, nacida en 1957).

Los sábados cantábamos canciones: Mariquita, Pío-pío, Cara al Sol, himnos. Hacíamos gimnasia cuando hacía buen tiempo (Verín, nacido en 1936).

Muchos elementos emocionales se pueden rastrear en estos fragmentos de oralidad de los que nos servimos aquí como fuente primaria de conocimiento. La memoria de la escuela, al recuperar las experiencias vividas en la infancia por los sujetos entrevistados, incluye alusiones a emociones y sentimientos ambivalentes: el dolor y la alegría, la satisfacción y el sufrimiento, los premios y los castigos, la diversión por el juego y el esfuerzo por el trabajo, incluidos los deberes. Algunos testimonios 
dan idea también de los regímenes emotivos vigentes en la familia y en las instituciones, así como en las relaciones entre los grupos infantiles y otros actores de la sociabilidad. Esta afectividad, ambivalente o bipolar en muchos aspectos, también se proyecta ahora al valorar los adultos, con la distancia del tiempo transcurrido, la experiencia del mundo de la educación en la que se formaron hace más de medio siglo, un ciclo medio-largo que permite contrastar el presente con los recuerdos.

Especial interés tiene a este respecto la memoria emocional que los sujetos guardan de quienes fueron sus primeros enseñantes, femeninos en unos casos y masculinos en otros. Son muchas las referencias explícitas a este respecto en los narratorios de los entrevistados. En unas se habla de las cualidades físicas y de la personalidad de los docentes rurales; en otras, de los métodos de enseñanza que empleaban y de la disciplina que imponían como medio de gobernar y regular la marcha de la clase. También se aludía a la precaria situación económica de los maestros y maestras y a las relaciones que mantenían con los demás miembros de la comunidad local. Transcribimos algunos de estos fragmentos. La imagen del enseñante está muy presente en los relatos de los sujetos entrevistados, lo que abona la interpretación de que el porte magistral constituía un claro referente tanto para los alumnos como para los demás habitantes de la población.

Mi profesora era muy mala. Era soltera; se casó aquí. Era bonita y cantaba bien (Vimioso, nacida en 1936).

La maestra era espectacular. Enseñaba bien. Era delgada y baja; tenía alrededor de 30 años. Vestía de forma clásica, elegante. Me gustaba mucho (Vimioso, nacida en 1936).

La maestra era bondadosa. En la aldea le llamaban la «santa». De mediana edad, vestía ropa más clara que las mujeres de la aldea (Vimioso, nacida en 1927).

Tengo recuerdos agradables y afectuosos de mi profesora; era como mi hermana. Era simpática, guapa y vestía bien (Vinhais, nacida en 1945).

Mi profesor fue siempre el maestro Ferreira. No tengo buena impresión de él. Era malo y exigente. Pegaba cuando había cual- 
quier acto de indisciplina o que perturbase la marcha normal de la clase (Chaves, nacido en 1945).

El profesor era buena persona, pero perezoso. No enseñaba casi nada; por eso no me gustaba (Miranda do Douro, nacido en 1924).

No eran muy diferentes los modelos de enseñantes a uno y otro lado de la «raya», ni tampoco las condiciones económicas y sociales en que se ejercía la profesión de la enseñanza en estos lugares transfronterizos de la Península Ibérica. Tampoco lo eran las relaciones de los docentes con los contextos sociales - todos ellos rurales en este caso- en que desenvolvían la profesión.

La profesora era nuestra amiga. Ganaba muy poco. Tenía cinco hijos y mis padres le daban cosas de lo que cosechaban. No enseñaba mucho porque tenía también que cuidar de los hijos. Era muy resignada; no se quejaba. El marido no se portaba muy bien con ella (Trabazos, nacido en 1945).

El maestro era buena persona, aunque no enseñaba mucho. Le andaban persiguiendo siempre los de Falange y a veces bebía con los hombres en la taberna del pueblo (Trabazos, nacido en 1945).

La maestra de Mezquita era moderna, aunque algo mala. No dejaba hablar ni salir del pupitre, aunque a veces enseñaba juegos (Mezquita, nacida en 1925).

Tuve varios profesores que estaban poco tiempo en el pueblo. Enseñaban poco. La mejor era D. ${ }^{a}$ Pilar, muy severa, pero buena maestra. El día de su santo nos invitaba en su casa a dulces (Verín, nacido en 1951).

Yo fui al colegio La Salle, donde había 8 profesores. El mío, el hermano Chivite, era un excelente profesor, bastante exigente, pero con él aprendimos mucho (Verín, nacido en 1935).

No me recuerdo mucho de él. Llevaba bigote y era calvo. Estaba siempre bien dispuesto a hacer cosas, ayudando al pueblo cuando había alguna celebración (Madrín, nacido en 1945). 
El maestro don Amancio, de unos cuarenta años, era buen profesor y hombre simpático. Se llevaba muy bien con todos los vecinos (Chaguazoso, nacido en 1950).

La caracterización que los adultos —entonces niños y niñas de escuela primaria o básica- hacen de los maestros y maestras de este territorio de uno y otro lado de la frontera incluye, como se habrá observado, muchos descriptores y enunciados que tienen que ver con el mundo emocional que rodeaba a la sociedad rural de la época y que se trasladaba a la escuela. Este universo afectivo formaba parte del emocionario colectivo y de las prácticas de educación sentimental asumidas por el ethos de las comunidades. No hay apenas diferencias entre el tenor de los testimonios de uno y otro lado de la raya y de una a otra región o comarca. La estructura económica y social, en buena medida homogénea, pese a algunas diferencias vernáculas, imponía un tipo de valores y comportamientos muy parecidos, así como una estimativa de emociones y sentimientos muy próxima entre unas y otras zonas.

\section{MEMORIA TERAPÉUTICA Y EMOCIONES}

En este apartado glosamos una experiencia llevada a cabo hace pocos años en el CEINCE - ya descrita en otras publicaciones- relativa a la reactivación de los restos de memoria que conservan en su cerebro-palimpsesto los sujetos afectados por demencias seniles o por la misma enfermedad de Alzheimer, en sus fases inicial e intermedia. Mediante la presentación como estímulos motores, cognitivos y emocionales de los objetos, textos e imágenes que fueron utilizados en la escuela, el programa trató de comprobar la persistencia de los recuerdos antiguos en la mente de los sujetos observados. Para no repetir los pormenores del experimento remitimos a la exposición sobre el tema que hicimos en nuestro reciente libro La cultura empirica de la scuola. ${ }^{20}$

El encuentro con el museo desencadena en los sujetos de la experiencia procesos de recuerdo y suscita emociones de infancia. Como se ha señalado anteriormente, el neurofisiólogo Antonio Damasio ha puesto énfasis en la interrelación que se da entre los procesos cognitivos, mne-

\footnotetext{
${ }^{20}$ Escolano, La cultura empirica della scuola, 170 ss.
} 
mónicos y emocionales. ${ }^{21}$ Las emociones y sentimientos que afloran en situaciones vinculadas a los recuerdos son conductas complejas, en buena medida automáticas, que han sido incluso seleccionadas y fijadas como los patrones de la evolución. Acciones como las que se observan en la imagen que apoya la explicación de esta experiencia implican globalmente a toda la corporeidad, desde la que afecta a las posturas corporales que adoptan los sujetos a la que se manifiesta en sus expresiones faciales y las que se operan, de manera no visible pero real y efectiva, en el medio fisiológico interno de la subjetividad. El «estado emocional», tal como lo describe Damasio, es una especie de situación derivada de una reacción en cadena de dispositivos complejos de carácter cognitivo, afectivo y neuromotor. Esto es lo que ocurre probablemente a los sujetos participantes en la experiencia que aquí comentamos.

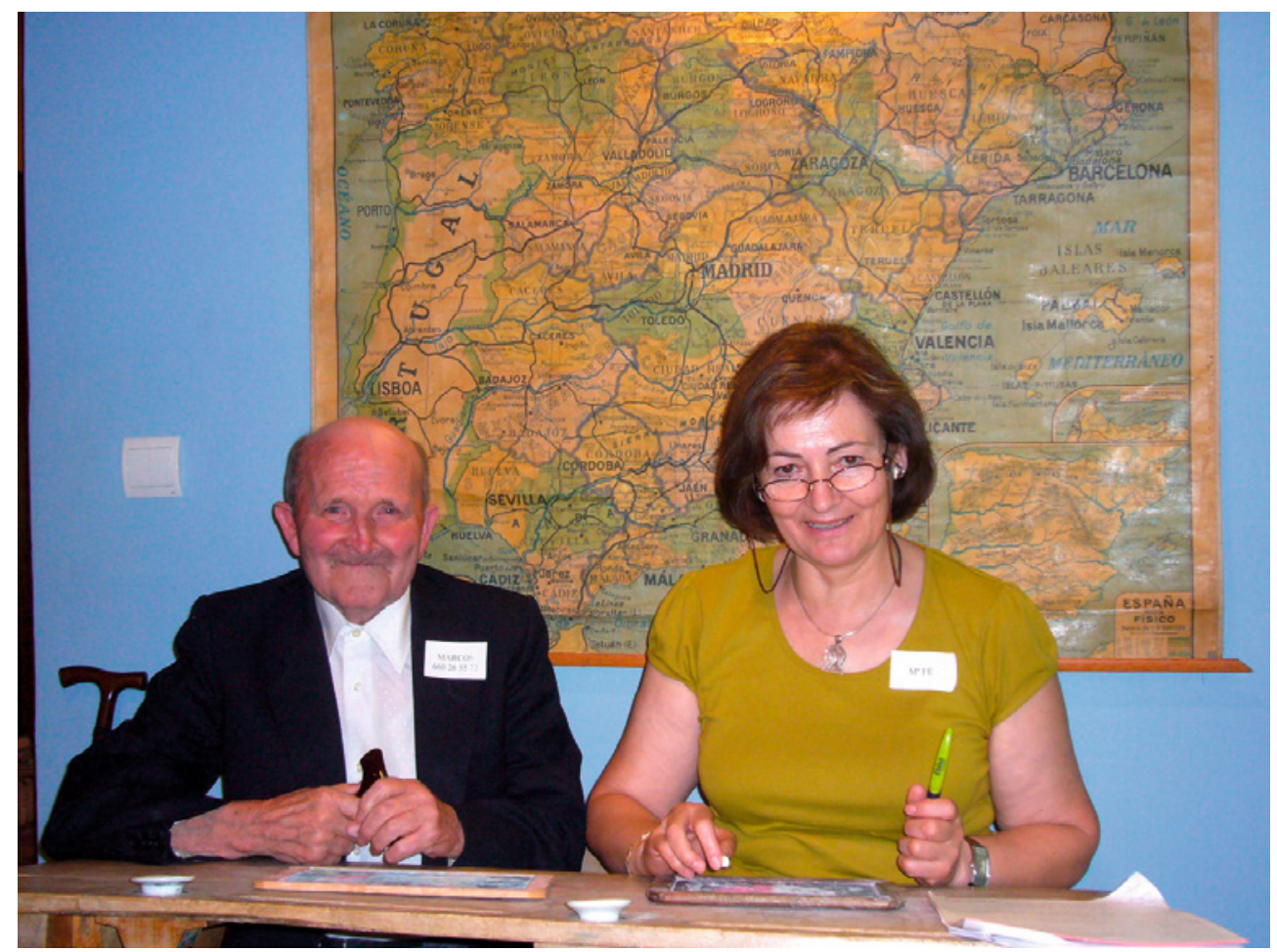

${ }^{21}$ Damasio, Y el cerebro creó al hombre, 196 ss. 


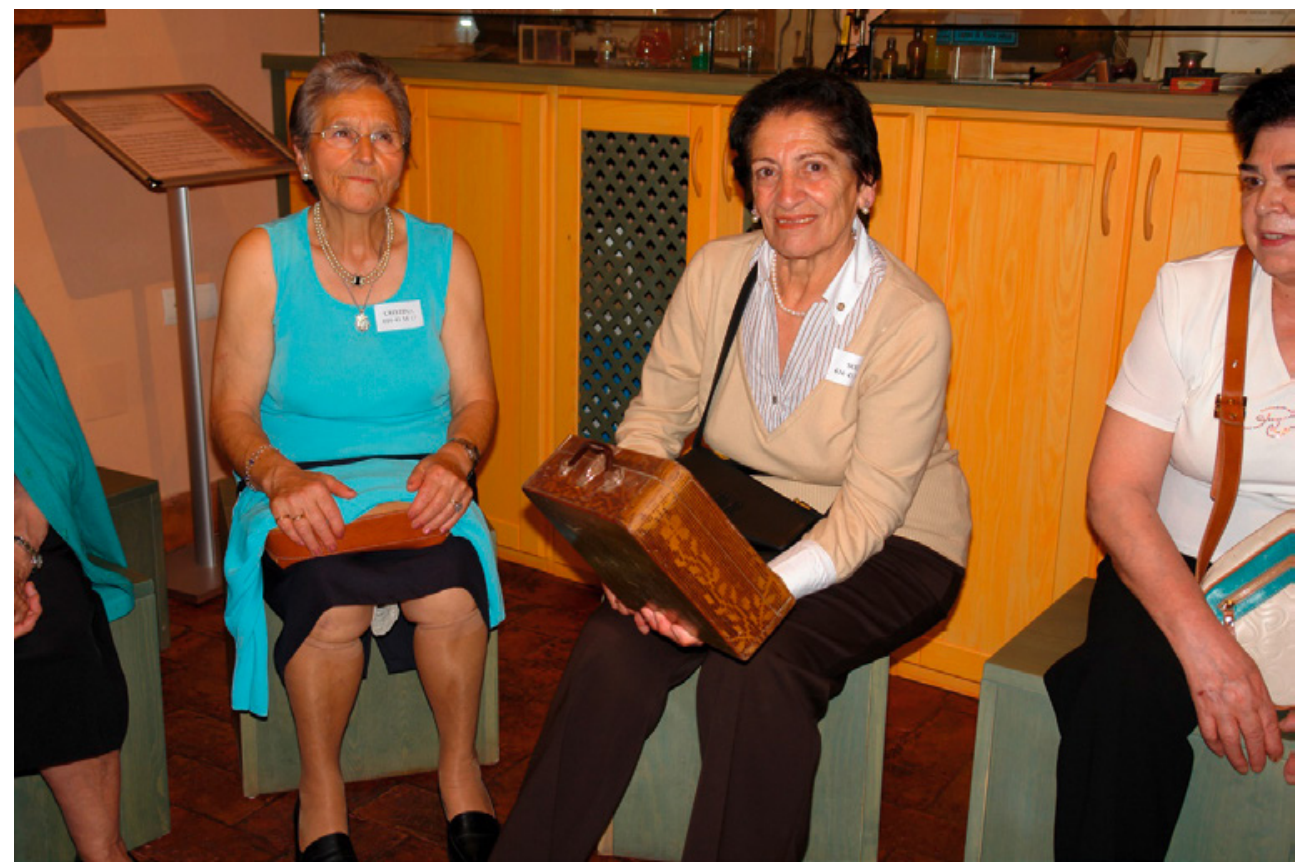

\section{EMOCIÓN TERAPÉUTICA}

Imagen de la experiencia con enfermos de Alzheimer. En ella el sujeto sonríe al sentarse, junto a la monitora que le acompaña, sobre un pupitre semejante al que ocupó durante su infancia escolar, una etapa muy alejada ya de su experiencia, pero que no ha borrado aún de la memoria. Su cuerpo no ha olvidado este anclaje ergonómico y antropométrico que proporcionó el mobiliario escolar. La memoria recupera emociones como esta con alegría. Y este recuerdo de su pasado infantil alivia en parte de las dolencias.

La segunda imagen corresponde a la misma sesión clínica en la que una anciana afectada de demencia senil reconoce el cabás o maletín como uno de los objetos cotidianos de escuela. En él portaba diariamente a clase los útiles de coser, bordar, dibujar y escribir. El encuentro con este viejo útil del ajuar escolar promueve emociones satisfactorias. 
El experimento trató de estimular intencionalmente los restos de memoria que mantienen estas personas afectadas por la enfermedad mediante la presentación como estímulos de objetos, imágenes, sonidos y manuales procedentes de la escuela a la que asistieron durante su infancia. Diseñado en colaboración con técnicos de la Asociación de Familiares de Enfermos de Alzheimer de Soria (psicólogos, médicos, terapeutas, asistentes sociales), el ensayo puso de manifiesto, entre otras cosas, varias conclusiones relevantes en relación a las emociones y sentimientos:

- La posibilidad de activación mediante estímulos competentes adecuados de los recuerdos depositados en estratos arqueológicos antiguos, escolares en este caso.

- El desencadenamiento de una actitud narrativa y emocional en los sujetos basada en los restos de memoria que aún permanecen con posibilidad de ser activados.

- El poder estimulador de los materiales escolares antiguos respecto a mecanismos cognitivos, emocionales, psicomotores y expresivos.

- La posibilidad de resocialización e interactividad empática de los recuerdos personales de unos y otros miembros del grupo.

- La creación de nuevas situaciones de sociabilidad que potencian el campo de memoria con la recuperación de los emocionarios colectivos, más allá de los registros estrictamente individuales.

La experiencia que hemos relatado se inspiró y planificó en parte en la lectura por parte de los profesionales intervinientes en el estudio del libro de Umberto Eco La misteriosa llama de la reina Loana, una obra en la que se narran las peripecias que sigue el personaje central del relato, Yambo Bodoni, que ha perdido la memoria personal o biográfica como consecuencia de un ictus cerebral, accidente al que logra sobrevivir. ${ }^{22} \mathrm{El}$ protagonista de la historia, para reconstruir su propia vida - o mejor dicho, la memoria colectiva o histórica de las personas de su generaciónva tomando contacto con los libros, imágenes y objetos que compartió

${ }^{22}$ Ver referencia en nota 16. 
durante la infancia con sus pares de edad y que dieron forma y contenido al ideario e imaginario de toda una época, la que corresponde a la posguerra mundial.

Por consejo de su terapeuta, el personaje del relato hace un viaje al desván de la casa en la que vivió sus primeros años, situada en una pequeña aldea al pie de las colinas del Piamonte italiano. En él (otro rincón arqueológico) se guardaban los manuales y los comics en los que el sujeto de la narración se había iniciado en la cultura letrada y en la iconografía de la época. También encontrará allí Bodoni objetos de infancia y adolescencia, escolares y no escolares, que igualmente habían constituido el bagaje material y emocional de los trabajos y los juegos compartidos con sus compañeros y familiares. Aunque él no lo sospechara, porque su dañado cerebro no lo podía reconocer, al situarse en aquel desván abandonado se estaba colocando ante la biblioteca y el museo que, a memoria ciega, le iban a proporcionar el contacto con las claves esenciales de la memoria colectiva y de la educación sentimental común a todos los hombres y las mujeres de su generación. Este era el nivel de memoria que se disponía a recuperar Bodoni para resituarse, reaprendiendo sus códigos, a la altura de su tiempo histórico.

El desván era, en este contexto experimental, un aula inmensa, un yacimiento donde se archivaba la cultura objetual, icónica y textual de él y de sus coetáneos. Yambo entraba en él, con sigilo reverencial y cuasi detectivesco, como quien accede a una caverna en la que se guardaba aún la enciclopedia y el tesoro de que se había nutrido la memoria emocional suya y la de todos los compañeros de edad. Su capacidad perceptiva no llegaba a identificar más que improntas o sombras nebulosas de las formas que tejieron las representaciones afectivas de su etapa infantil, pero sin duda, frente a aquella epifanía, el sujeto narrativo volvía a tomar contacto con los estímulos empíricos que, de no haber sufrido el accidente neurofisiológico, recordaría ahora con absoluta claridad.

Yambo Bodoni penetraba en esa caverna, a la que, por consejo terapéutico, tenía que ingresar él solo, como Tom Sawyer, intentando explorar en aquel laberinto, entre sombras y penumbras, las señales de un micromundo cognitivo y sentimental ubicado en la planta en la que la 
casa limitaba con el paraíso celeste, el bajo cielo. Si una bodega anunciaba los infiernos, un desván podía prometer un paraíso - advierte con sutileza Umberto Eco-. En su labor minuciosa y casi detectivesca, al modo de Sherlock Holmes, ${ }^{23}$ el personaje no encuentra ya recuerdos, que han sido borrados irreversiblemente de su memoria personal, sino indicios motivadores para formularse a sí mismo conjeturas acerca de lo que fue suyo, y que ahora necesitaba reaprender para situarse al nivel de la memoria colectiva en que se materializaba la experiencia histórica compartida por todos los menores que crecieron bajo el influjo de la cultura fascista y de la de posguerra en la Italia de aquel tiempo. No obstante, la violencia simbólica que llevaban adherida muchas de aquellas señales o huellas de los objetos, textos e imágenes, la biblioteca y el museo de la infancia albergaban un tesoro de valor incalculable, con cuyo contacto el personaje creado por Eco sentía poder retornar a lo que él parecía intuir como las emociones del paraíso perdido de la infancia y la adolescencia.

Era aquella una memoria material, neblinosa y en mosaico, casi browniana — confesaba el narrador al final de la laboriosa investigación-, pero esta aproximación a las fuentes de sus primeras improntas culturales le había puesto seguramente en situación para acercarse a ver el centro de su aleph, donde podría adivinar, quizás como en un sueño, la «cartilla» de sus primordiales recuerdos y sentimientos, esto es, los códigos de la caja negra de su oscura y opaca mente. Reaprendiendo esta vieja gramática, el personaje Yambo Bodoni iba a colocarse ya en condiciones de volver a conectar emocional y sentimentalmente con sus iguales o compañeros de escuela, con su lenguaje, sus emociones, su cultura. ${ }^{24}$

Umberto Eco explica en esta novela-ensayo cómo los textos, iconos y objetos son contenedores semánticos «semióforos», esto es, fuentes materiales portadoras de señales cognitivas y emocionales, que pueden ser reaprendidas desde la amnesia sobrevenida o descodificados mediante la estrategia de la sospecha. Como se recordará, también

\footnotetext{
${ }^{23}$ Agustín Escolano, «Sherlock Holmes goes to school. Etnohistory of the school and educational heritage», History of Education and Children's Literature, 2 (2010): 17-32.

${ }^{24}$ Agustín Escolano, «La cultura material de la escuela», en La cultura material de la escuela, ed. Agustín Escolano (Berlanga: CEINCE, 2007), 23-25.
} 
Guillermo de Baskerville, ficticia encarnación de Sherlock Holmes, mostraba a su joven discípulo Adso en El nombre de la rosa las huellas para investigar por abducción (como en la semiología de Charles S. Peirce) las tramas criminales que acontecieron en la misteriosa abadía de Melk. La narratividad, que siempre es compañera inseparable de la hermenéutica, su prerrequisito, cumple aquí una función pragmática, la de ser reveladora de las tramas de sentido que comporta una semiología asociada a la investigación de la cultura material, y la de contribuir, entre la estética y los sentimientos, a la educación histórica de las personas.

Pues bien, el experimento acerca de los usos terapéuticos del patrimonio escolar comentado se inspira, como se ha dicho, en el discurso subyacente en este sugerente relato de Umberto Eco. Los sujetos afectados por algún tipo de demencia senil o por el síndrome de Alzheimer tienen como es sabido importantes pérdidas de memoria, pero el contacto con determinados estímulos emocionales competentes como los que les ofrece la cultura material de la escuela a la que ellos asistieron hace muchos años, guardados aún en parte en el complejo palimpsesto de su memoria emocional, motórica y cognitiva, puede hacer reactivar determinados contenidos que todavía se conservan en algún estrato arqueológico del entramado de la complicada mente humana.

La historia de las emociones conecta aquí con la antropología. El experimento etnográfico que hemos descrito nos descubre el interés que tiene el poder indagar en el pasado biográfico y en la historia emocional de las sociedades. Entre ambos registros, el personal y el colectivo, hay claves que comunican a los sujetos y las culturas en términos afectivos e intelectuales. Ello avala el interés que las democracias ilustradas de nuestro tiempo muestran por recuperar la cultura material e intangible de la vida escolar, en las que se hace presente la memoria, y asimismo por poder difundir todos estos bienes en la sociedad en orden a la educación patrimonial, sentimental e intelectual de los ciudadanos. 


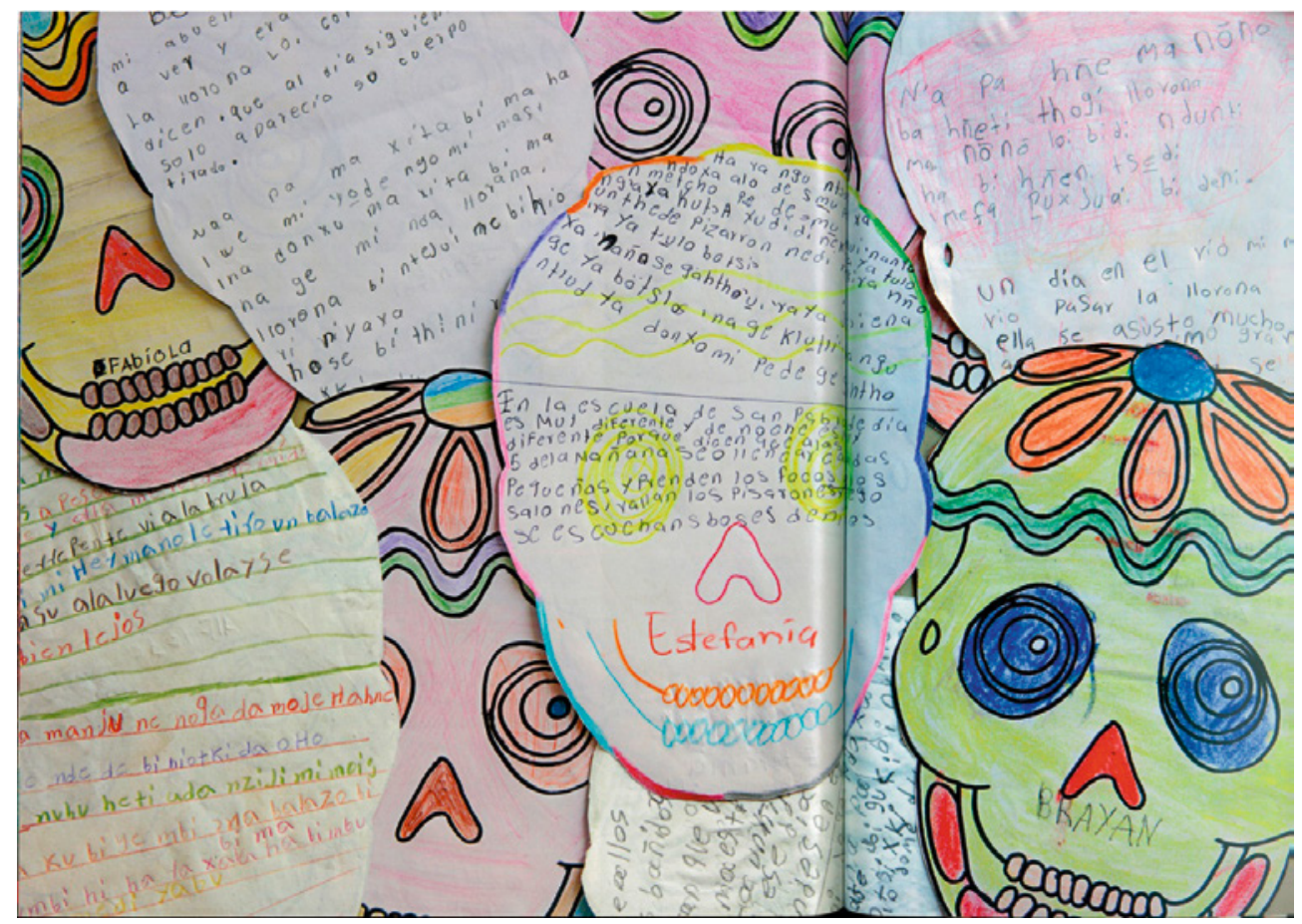

\section{EMOCIONES VERNÁCULAS}

Cuadro de emoticonos dibujados por niños y niñas de una escuela de Chiapas, México. En las imágenes y en los textos se entrecruzan signos que remiten a la superposición de emociones de raíces vernáculas con lenguajes de la cultura de Estado. Los hilos del presente se enredan, como en el relato de Saramago, en el tejido del pasado.

José Saramago se acercó con prosa poética a entrever las conexiones en las que los hilos del presente se enredan en el tejido del pasado. Lo hizo en dos conocidos narratorios: el Ensayo sobre la ceguera y el Ensayo sobre la lucidez. Y también en un breve relato en el que narra algunas vivencias de su abuelo, aquellas que la memoria del anciano no había perdido aún. Hombre sabio y callado, aquel abuelo aún miraba a lo lejos, a menudo en una especie de diálogo mudo con el mundo, con su rostro tallado por la experiencia de la vida, pero expresivo en el brillo de sus ojos. Con el caudal de su infancia remota, el viejo avanza en silencio bajo 
la lluvia, acompañado de su memoria, una reserva de energía y cultura que le auxilia, a la espera de la gran sombra, en las respuestas que ha de dar a los interrogantes de la estrellas. ${ }^{25}$

Aquella memoria era un reservorio inteligente sin duda, pero también emocional, una especie de energeia que el tiempo de la evolución transformaría en instinto orientado a la conservación de la vida o a la transmisión de la cultura en la comunión con las nuevas generaciones, en definitiva, a la continuidad evolutiva de la especie humana. Memoria y emociones adquieren así un claro significado antropológico, al que la historia de la educación se acerca hoy desde el giro afectivo que asumen las nuevas orientaciones historiográficas.

\section{Nota sobre el autor}

Agustín Escolano Benito es catedrático de Historia de la Educación de la Universidad de Valladolid y fundador-director del Centro Internacional de la Cultura Escolar (CEINCE) con sede en Berlanga de Duero, España. Anteriormente fue catedrático de la Universidad de Salamanca, donde fundó la Revista Interuniversitaria de Historia de la Educación, que dirigió durante cerca de treinta años, y las series Studia Paedagogica y Ciencias de la Educación. También ha ejercido en otros periodos en las universidades Complutense de Madrid, Oviedo y Autónoma de Barcelona. Ha sido presidente de la Sociedad Española de Historia de la Educación y miembro de comité ejecutivo de la ISCHE. Es doctor honoris causa por la Universidad de Lisboa y doctor honorario del Colegio de Doctores de Salamanca, así como profesor visitante de las universidades italianas de Macerata, Ferrara, Molise y Bolonia. Entre sus publicaciones destacan: La investigación pedagógica universitaria en España (1980), Educación y economía en la España ilustrada (1988), Estudios de historia social de la educación (1983), Historia de la Educación I y II. Diccionario 1085), Leer y escribir en España. Doscientos años de escolarización (1992), L'Educazione in Spagna (1992), Historia ilustrada del libro escolar en España (2 vols, 1997-1998), Tiempos y espacios para la escuela. Ensayos históricos (2000), El pensil de las niñas (2001), La educación en la España contemporánea (2002), Historia ilustrada de la escuela (2006), Currículum editado y sociedad del cono-

\footnotetext{
${ }^{25}$ José Saramago, «Mi abuelo, también», en La emoción de educar. Reflexiones y vivencias en torno a la educación (Madrid: SM, 2010), 47-49.
} 
cimiento (2006), La España cubista. Visiones desde la escuela (2015), La cultura empírica della scuola (2016, ediciones en portugués y español en 2017). Actualmente se ocupa de diversas temáticas relativas al campo de la cultura escolar.

\section{Referencias}

Agualusa, José Eduardo. O vendedor de pasados. Lisboa: Publicaçôes Dom Quixote, 2004.

BARRETT, Richard. A new psychology of human well-being. London: Barrett Values Centre, 2015.

Borges, Jorge Luis. Poesías. Barcelona: RBA-Instituto Cervantes, 2005.

Bourdieu, Pierre. El sentido práctico. Buenos Aires: Siglo XXI, 2007.

BRUNER, Jerome. La educación, puerta de la cultura. Madrid: Visor, 2000.

CEINCE. «Nos visitaron: José Jiménez Lozano». Papeles del CEINCE 13 (2013).

Escolano Benito, Agustín. «La arquitectura como programa. Espacio-escuela y currículum». Historia de la Educación 12-13 (1993-94): 97-99.

- «La cultura material de la escuela». In La cultura material de la escuela, edited by Agustín Escolano. Berlanga: CEINCE, 2007.

- «Sherlock Holmes goes to school. Etnohistory of the school and educational heritage». History of Education and Children's Literature 2 (2010): 17-32.

- La cultura empirica della scuola. Esperienza, memoria, archeologia. Ferrara: Volta la Carta, 2016.

Giacomini, Gabriele. Psicodemocrazia. Quanto l'irracionalità condiziona el discurso público. Milano: Mimesis, 2016.

Goleman, Daniel. Inteligencia emocional. Barcelona: Kairós, 1996.

Muñoz Molina, Antonio. «La emoción de las cosas». Facsímil de la Cartilla Escolar Antifascista. Madrid: Viamonte, 1997.

Ricoeur, Paul. Tiempo y narración III. El tiempo narrado. México: Siglo XXI, 1996.

Rodrigues Gomes, Marilia J. A realidade educativa no nordeste portugués e nas escolas castelhano-leonesas e galegas fronteiriças, através da memoria oral, na época das ditaduras. PhD diss, Campus Ourense-Universidad de Vigo, 2015.

SARAmago, José. "Mi abuelo, también». In La emoción de educar. Reflexiones y vivencias en torno a la educación, 47-49. Madrid: SM, 2010.

STEINER, George. Lecciones de los maestros. Madrid: Siruela, 2005. 